\title{
Development of Microsoft Excel-based Interactive Media on Chemical Reaction Balancing
}

\author{
Rauzatur Rahmi ${ }^{1}$, Ibnu Khaldun² ${ }^{\star}$, Mustanir Mustanir ${ }^{3}$ \\ ${ }^{1}$ Science Education Study Program, Postgraduate Program, Syiah Kuala University, Banda Aceh, Indonesia \\ ${ }^{2}$ Chemical Education Study Program, FKIP Syiah Kuala University, Banda Aceh, Indonesia \\ ${ }^{3}$ Department of Chemistry, FMIPA, Syiah Kuala University, Banda Aceh, Indonesia
}

DOI: $10.29303 /$ jppipa.v7i3.612

\section{Article Info}

Received: January 30th 2021

Revised: June 20th 2021

Accepted: July 7th, 2021

\begin{abstract}
All schools in general already have adequate technology and information facilities. Teachers and students can use computers as learning media usually the existing media are only in the form of powerpoints which tend to be teacher-centered, It is necessary to have interactive learning media in the learning process, one of which is Microsoft excel-based interactive media on chemical reaction equalization material, especially metathesis reactions. The name of the developed media is Chem React, which is a chemical reaction. This study aimed to determine the feasibility of Chem React media as a chemistry learning medium and to determine the responses of teachers and students to the development of Chem React media. This study uses the ADDIE research and development model. The sampling technique was carried out by purposive sampling, namely 15 students who were able to use computers and ten chemistry teachers. The procedure for collecting data was needs analysis, design, development, validation, media revision, small-scale testing, and evaluation. Data analysis techniques calculated the feasibility of the media, student, and teacher responses. The results of the feasibility assessment by media and material experts obtained an average rating of $92.97 \%$, in the very good category. The results of teacher responses of $91.50 \%$ and student responses of $90.33 \%$ fall into the very good category. So the Chem React media is very suitable to be used as a learning medium on chemical reaction balancing material.
\end{abstract}

Keywords: Media interactive; Microsoft excel; Chem React; media development.

Citation: Rahmi, R., Khaldun, I., \& Mustanir, M. (2021). Development of Microsoft Excel-based Interactive Media on Chemical Reaction Balancing. Jurnal Penelitian Pendidikan IPA, 7(3), 408-413. doi:https://doi.org/10.29303/ippipa.v7i3.612

\section{Introduction}

Equalization of chemical reactions is one of the second semester's chemical materials taught in class $X$ SMA. Chemical material requires a lot of explanation and supporting media in the learning process to convey it (Padmanaba et al., 2018). This is because most of the chemistry tends to be abstract (Kharolinasari et al., 2020).

The results of observations that occur during the learning process students only use chemistry textbooks as a learning resource, and in the chemistry learning process, the teacher only uses PowerPoint, which tends to be teacher-centered where students look passive.
Students in schools that have been surveyed still feel that chemistry is a difficult subject in high school. This can be seen from the low learning outcomes based on the National Examination for Studies results. One of them is stoichiometric material on chemical reaction equation indicators, for the last three years, from 2015/2016 to $2018 / 2019$, the percentages were $20.69 ; 31.25$ and $14.29 \%$ (Puspendik 2016, 2018, 2019). This shows that students' ability to solve chemistry problems is still relatively low.

Students' abilities can be optimized with practice questions and continuous independent study by utilizing IT as a learning medium. Therefore, teachers are expected to be able to create interesting and effective 
learning media. Learning using computer-based simulations has a positive value for understanding chemical concepts (Jane et al., 2017). One of them can develop interactive media by utilizing Microsoft Excel software. Learning media using Microsoft Excel is a more interactive tool that can help students better understand concepts (Bernard et al., 2018). The use of Microsoft Excel software as an interactive learning media looks very effective in solving learning problems. Microsoft Excel software functions as an interactive medium that students can use independently and can learn anytime and anywhere (Astuti \& Bhakti, 2018b).

Microsoft Excel can be designed into a program in the form of learning media that can be run according to the instructions for use, and Microsoft Excel can also be designed to solve chemical reaction balancing quickly and precisely (Anizar et al., 2018). Simulation of chemical reactions is simple using Microsoft Excel, can be studied easily, costs less, and can show reactions as carried out in real experiments (Naseri et al., 2016).

Interactive media is a medium that helps students learn to be actively involved during learning by means of students having to interact with the media used during learning (Susilana \& Riyana, 2009). Interactive learning media is a form of media that uses information technology that can improve the quality of chemistry learning (Satriawan et al., 2020). Interactive learning media is a learning media that forms interactions between users and the media, which serves to deliver learning materials to students (Yanto, 2019).

This research develops a learning media that utilize ICT in Microsoft Excel software on chemical reaction balancing material. This media is expected to be suitable for use as a medium for learning chemistry in chemical reaction balancing materials. The novelty finding in this study is that students can balance chemical reactions using a Microsoft Excel software application that has been programmed into a learning medium in the form of Media Chem React. Chem React media was developed to help students learn to balance chemical reactions by themselves using this media. Through the use of this media, students can learn independently wherever and whenever, especially during an emergency of the 19th pandemic, especially in chemical reaction balancing material.

\section{Method}

This study uses research and development, with the ADDIE model, consisting of five stages: analysis, design, development, implementation, and evaluation. The study was conducted at SMA Negeri 2 Sigli in class XI IPA 1. Sampling was carried out by purposive sampling, namely 15 students who were able to use computers and ten chemistry teachers. The research sample was selected based on research conducted on students who have studied chemical reaction balancing in class X semester II. The research procedure is needs analysis, media design, media development, media validation, media revision according to the validator's suggestion, small-scale trials, and evaluation. The research instrument used was a media and material validation sheet, a teacher and student response questionnaire sheet. The data analysis technique was carried out as an assessment of the media feasibility test and analysis of student and teacher response sheets.

\section{Result and Discussion}

\section{Analysis}

The needs analysis results that were reviewed on five aspects, namely problems, characteristics, objectives, processes, and results, found that the school facilities provided were quite adequate, such as a multimedia room and two computer laboratory rooms. Teachers should be able to use several other media in every chemistry lesson. Therefore it is necessary to develop a Chem React media on chemical reaction balancing material. This media in addition to conveying learning in an interesting way, can also make it easier for students to complete and balance chemical reactions quickly and precisely. Students do not linger on equalizing chemical reactions with this media, so students have more time to learn chemical concepts (Bharathy, 2015). In addition, this Chem React media has never been used before at the high school, so it is expected to be able to help the chemistry learning process in chemical reaction balancing material.

\section{Design}

The results of the design and design starting from the cover, media menu, instructions for using media, student biodata pages, Chem React program, evaluation questions, and grades pages can be seen in Figures 1, 2, 3,4 , and 5 .

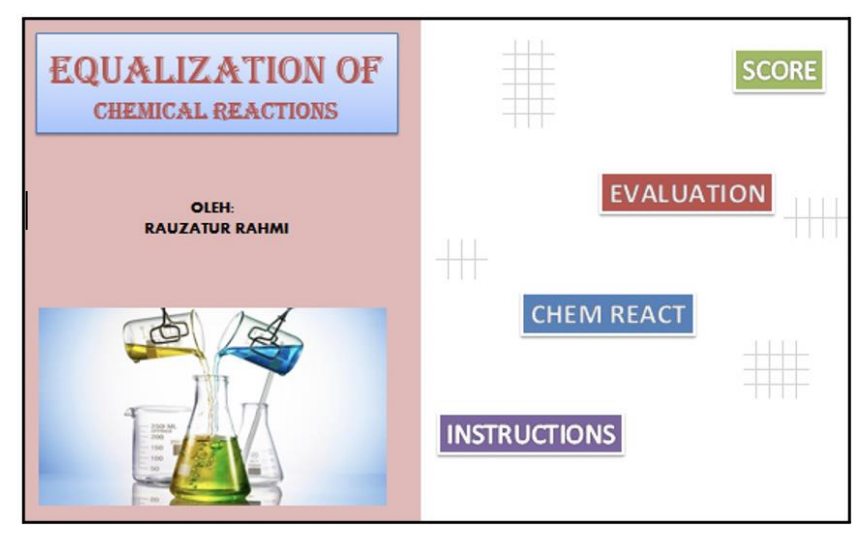




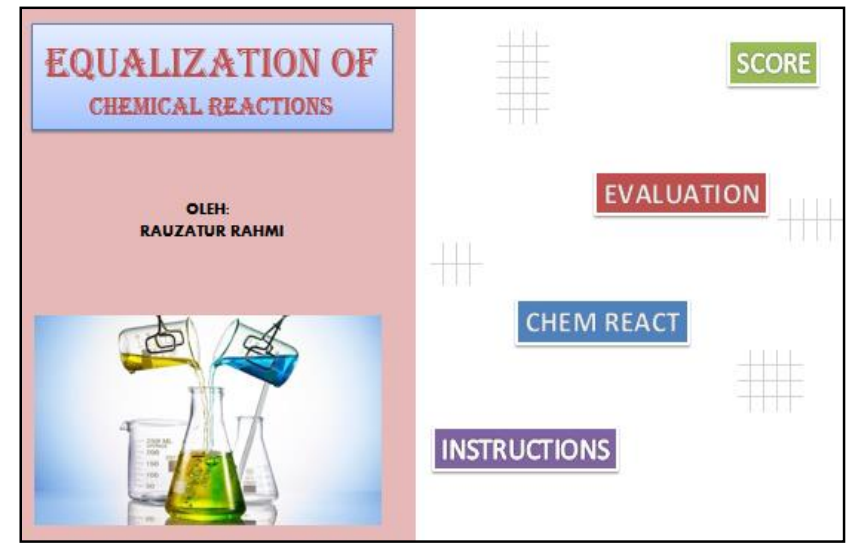

Figure 1. Initial cover design and media menu display menu

Figure 1. shows the initial design of the media in the form of a cover and the main menu of the media, namely the instructions menu, chem react, evaluation, and score.

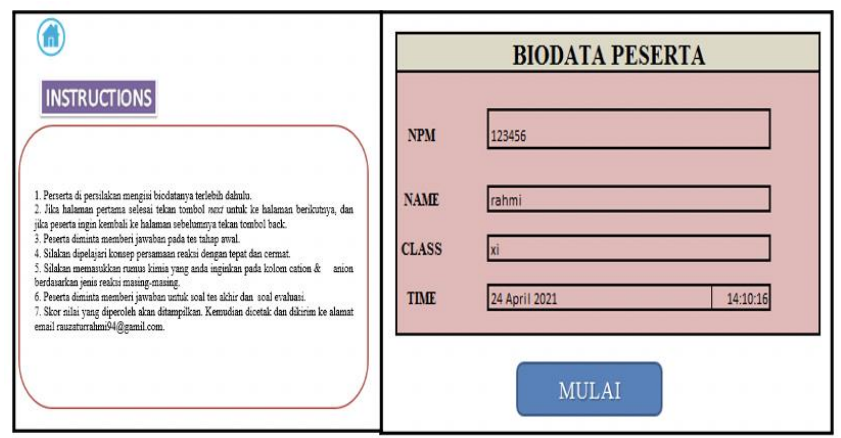

Figure 2. Initial view of the instructions page and participant biodata

Figure 2. is the initial view of the instruction page using the media, and the student biodata page. This biodata page in the operation of filling out the biodata is still not optimal, so at the development stage it is changed to be more systematic for filling in the biodata.

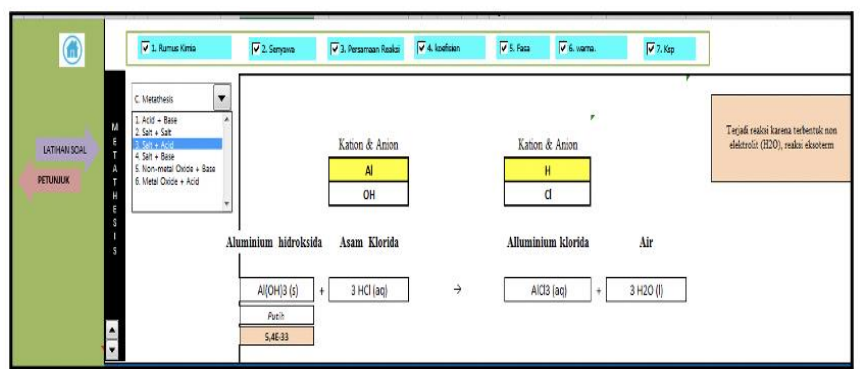

Figure 3. Initial design of the Chem React application.

Figure 3. shows an application image in the form of a program designed to make it easier for students to balance chemical reactions.

\section{EVALUATION}

1. Complete and balance the following equation for the reaction! $\mathrm{Al} 2 \mathrm{O} 3+\mathrm{CO} \rightarrow$

\section{ANSWER :}

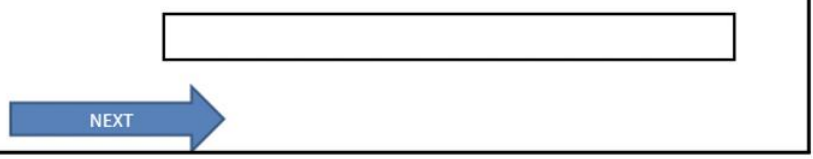

Figure 4. The initial design of student evaluation

Figure 4. is an evaluation display that is published in the media in the form of 50 questions for balancing chemical reactions.

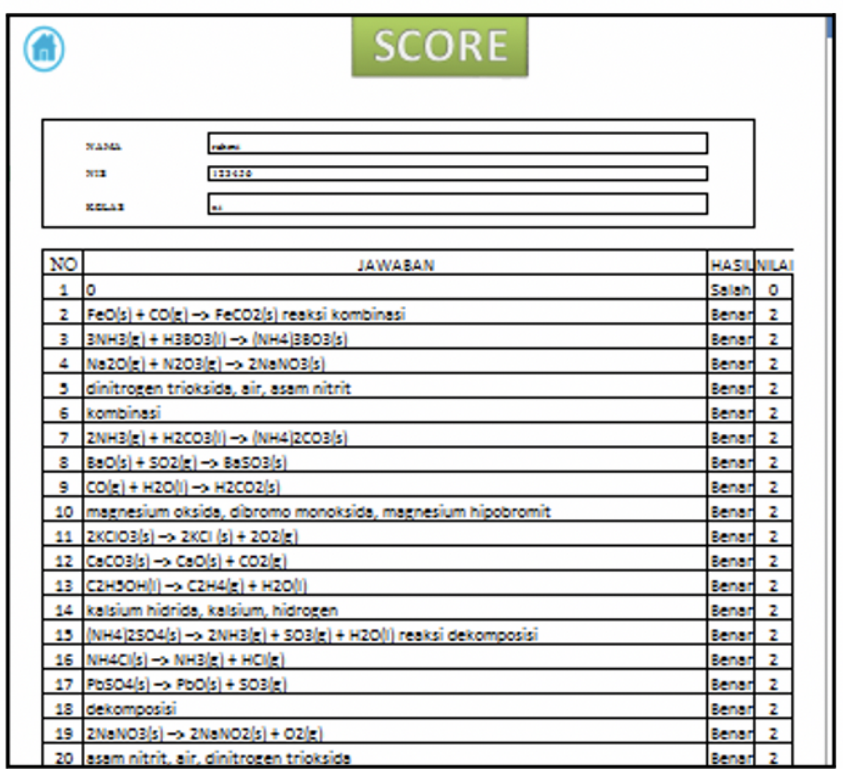

Figure 5. The initial design of student evaluation scores

Figure 5 initial view of the score page for the evaluation results. This score will be displayed at the end of the use of the media, namely after students have completed all the questions in the media.

\section{Development}

The results of media development based on input from media and material experts, Chem React media is obtained which is more attractive and good, both in terms of appearance, usability, quality of content, language, and operation. So that the developed media can be a tool in the chemistry learning process and can make it easier for students to understand the material and can help students in independent learning. The 
results of the media validity test by material and media experts can be seen in Figure 6.

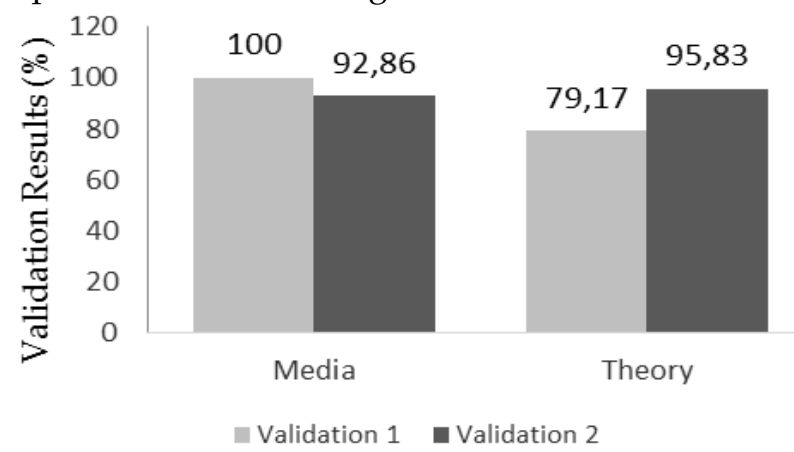

Figure 6. The results of the validity of media and materials

Chem React media validity test obtained an average value of $98.44 \%$. Based on the four aspects assessed against the Chem React media, it can be seen in Figure 4.18, the validation value obtained from each aspect, namely (1) the display aspect of $93.75 \%$, is categorized as very valid. According to a report (Siregar et al., 2020), the media display design aspect is very good if the achievement rate is $85-100 \%$. (2) aspects of media use obtained a value of $100 \%$. According to (Jannah et al., 2019), for the use of interactive media in learning, if the validity value obtained is at the level of achieving a score of $81-100 \%$, it is very valid. (3) aspects of the operation of the Chem React media obtained a score of $100 \%$ in the very good category. According to (Mudinillah, 2019) the acquisition value of the media operation aspect is $>96.2 \%$, already in the very good category and (4) the language aspect obtained a score of $100 \%$ already in the very good category. According to (Mudinillah, 2019) with the acquisition of a language aspect value of $>93.8 \%$, it is in the very good category. Based on the instrument's validation criteria (Sugiono, 2018 ), if the validation value is $>81$, it is very good. In this study, the minimum value obtained is $98.44 \%$, meaning that the validity category is very good.

The validity of the material obtained an average value of $87.50 \%$, for the three aspects assessed, as shown in Figure 4.19. The validation value obtained from each aspect, namely (1) the content/material obtained a value of $87.50 \%$, has been categorized as very good. According to the explanation (Jannah et al., 2019), the media content/material used is very valid if the validity value obtained is at the level of achieving a score of $81-100 \%$. (2) the language aspect obtained a value of $87.50 \%$. According to (Septyanti et al., 2020), interactive media uses standard language to be easily understood by students, plus an explanation (Satriawan et al., 2020) if the level of achievement of the score is between $85-100 \%$, it is categorized as very valid, and (3) aspect of the display obtained a value of $87.50 \%$. According to the explanation (Fitriani et al., 2020), if the media display's validity value is obtained between $80-100 \%$, it is categorized as very valid. According to the instrument validation criteria, the validation results of each material aspect in the Chem React media are in the very good category, according to the instrument validation criteria (Sugiono, 2018). All instruments can be used as measuring tools in research if the validation results are categorized as good because the instrument must be able to function properly (Septyanti et al., 2020).

\section{Implementation}

This research is limited to the trial stage on a small scale, considering that we must maintain health protocols currently in the Covid-19 condition. However, these results are still valid, based on the responses given by teachers and students to the very good Chem React media. Small-scale trials were carried out in one school, SMA Negeri 2 Sigli, using 15 students and ten chemistry teachers. Experiments on chemistry teachers were conducted to obtain teacher responses to Chem React media. The percentage of teacher responses obtained can be seen in Figure 7.

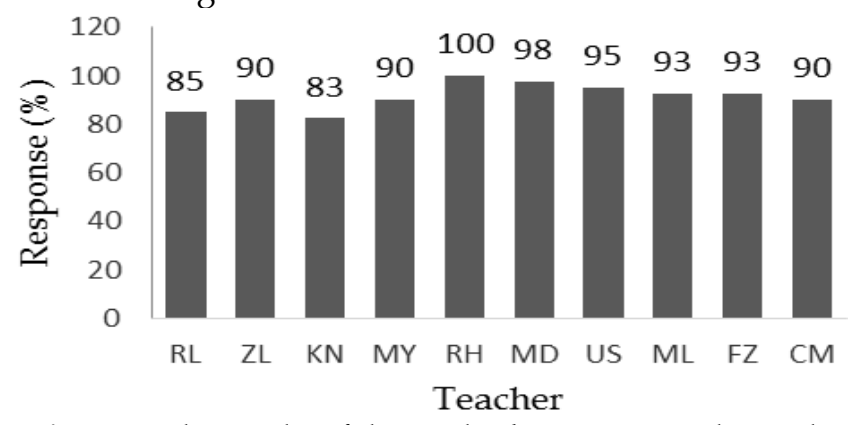

Figure 7. The results of the teacher's response to the media Chem React

The average value of the teacher's response to the Chem React media as a whole was obtained at $91.50 \%$. Based on the explanation (Arikunto, 2010) according to the response criteria table, if the response value obtained is $>81$, then the minimum value obtained is very good. This shows that the Chem React media is worthy of being a medium for learning chemistry, especially chemical reaction balancing materials. This media is able to help students during learning because interactive media can create interactions between students and objects that can motivate students to learn, and students look active during learning (Rahman et al., 2014). Microsoft excel-based learning media can be a new alternative for teachers in terms of using learning media (Astuti \& Bhakti, 2018a) because learning by using this media, as seen in the process of using Chem React media, this media is able to help students solve the problem of equalizing chemical reaction.

Tests on students were carried out to get students' responses to Chem React media. The percentage of 
responses obtained from each student can be seen in Figure 8.

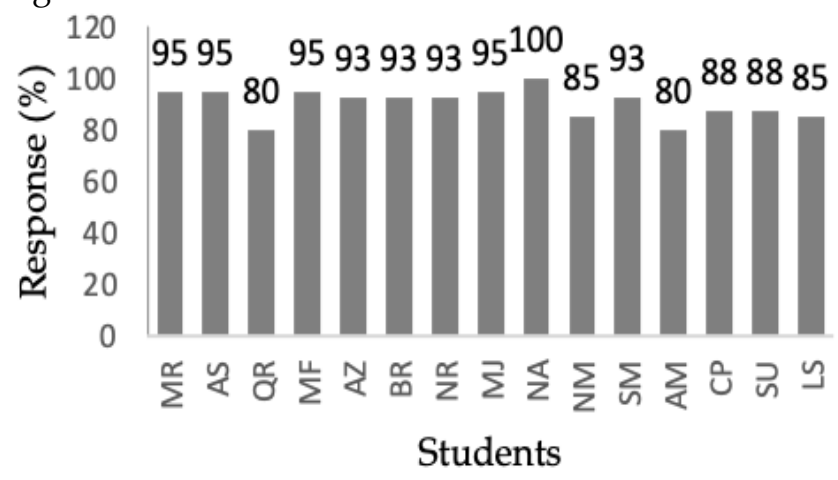

Figure 8. The results of students' responses to the media Chem React

The response of 15 students to the Chem React media obtained an average score of $90.33 \%$. According to the explanation (Arikunto, 2010) based on the response criteria table, if the response value is $>81$, then the minimum score obtained is very good. Based on observations in the product trial process, students seemed very interested in using Chem React media to balance chemical reactions. Apart from being interesting, Chem React media can also make it easier for students to learn and help students balance chemical reactions. Chem React can help students learn independently wherever and whenever (Astuti \& Bhakti, 2018b).

\section{Conclusion}

Based on the research on the Development of Chem React media that has been carried out, it can be concluded that Chem React media is suitable for use as a chemical reaction balancing medium. The teacher gave a very good response to the Chem React media, with a score of $91.50 \%$. Students gave very good responses to Chem React media, with a score of $90.33 \%$.

\section{Acknowledgments}

The author expresses his deepest gratitude to the supervisors and examiners who have taken the time to provide questions, input, and suggestions. The author also expresses his gratitude to the validators who have taken the time and reviewed the research instruments. The authors also express gratitude to the chairperson and staff of the Master of Science Education Study Program at Syiah Kuala University for their contribution as a facilitator who always takes the time and provides excellent service. And to the chemistry subject teachers, principals, and students of SMA Negeri 2 Sigli for their contribution as facilitators during research data collection.

\section{References}

Anizar, Gani, A., Khaldun, I., \& Bahi, M. (2018). The development of a module with Microsoft Excelbased interactive media on the topic of buffer solution. Journal of Physics: Conference Series, 1088, 12119. doi: https://doi.org/10.1088/17426596/1088/1/012119.

Arikunto, S. (2010). Prosedur Penelitian. Jakarta: Cipta, Rineka. [Indonesian]

Astuti, I. A. D., \& Bhakti, Y. B. (2018a). Interactive Learning Multimedia Based Microsoft Excel On The Temperature And HeaT. Unnes Science Education Journal, 7(1), 1-6. doi 10.15294/usej.v7i1.21355

Astuti, I., \& Bhakti, Y. (2018). The Effect of the Microsoft Excel based Interactive Learning Media on the Physics Problem Solving. Indonesian Review of $\begin{array}{lll}\text { Physics, } & \text { 7(1), }\end{array}$ doi:https://doi.org/10.12928/irip.v1i1.243

Bernard, M., Minarti, E. D., \& Hutajulu, M. (2018). Constructing student's mathematical understand ing skills and self : math game with visual basic application for Microsoft Excel in learning phytagoras at Junior High School. International Journal of Engineering \& Technology, 7(3.2), 732736.

doi: https://doi.org/10.14419/ijet.v7i3.2.18738

Bharathy, J. B. (2015). Importance of computer assisted teaching \& learning methods for chemistry. Science Journal of Education, 3(4-1), 11-16. doi: https://doi.org/10.11648/j.sjedu.s.2015030401.13

Fitriani, O., Susilawati, \& Linda, R. (2020). Development of interactive learning media using autoplay studio 8 for hydrocarbon material of class XI Senior High School. Journal of Educational Sciences, $4(2)$, 296-308. doi: http://dx.doi.org/10.31258/jes.4.2.p.296-308 Jane, M. W., Wachanga, S. W., \& Anditi, Z. O. (2017). Effects of computer-based simulations teaching approach on students ' achievement in the learning of chemistry among secondary school students in Nakuru Sub County , Kenya. Journal of Education and Practice, 8(5), 65-75. Retrieved from: https://eric.ed.gov/?id=EJ1133108

Jannah, M., Copriady, J., \& Rasmiwetti, R. (2019). Development of interactive learning media using autoplay media studio 8 for colloidal chemistry material. Journal of Educational Sciences, 3(1), 132144. doi: https://doi.org/10.31258/jes.3.1.p.132$\underline{144}$

Kharolinasari, R., Susatyo, E. B., \& Sarwana. (2020). Pengembangan media pembelajaran interaktif happy chemist pada materi hidrolisis untuk mengukur pemahaman konsep siswa. Jurnal 
Inovasi Pendidikan Kimia, 14(1), 2547-2560. Retrieved from: https://journal.unnes.ac.id/nju/index.php/JIPK /article/view/20283

Mudinillah, A. (2019). The development of interactive multimedia using lectora inspire application in Arabic language learning. Jurnal Iqra' : Kajian Ilmu Pendidikan, 4(2), 285-300. doi: https://doi.org/10.25217/ji.v4i2.570

Naseri, A., Khalilzadeh, H., \& Sheykhizadeh, S. (2016). Tutorial review: simulation of oscillating chemical reactions using Microsoft Excel Macros. Analytical, And Bioanalytical, Chemistry, Research, 3(2), 169-185. doi: https://doi.org/10.22036/abcr.2016.15812

Padmanaba, I. K. G., Kirna, I. M., \& Sudria, I. B. N. (2018). Pengembangan media pembelajaran interaktif kimia koloid berbantuan komputer untuk siswa SMA. Jurnal Pendidikan Kimia Indonesia, 2(1), 1525. doi:

http://dx.doi.org/10.23887/jpk.v2i1.14126 [Indonesian]

Rahman, M. J. A., Arif, M. H. I., \& Nasir, M. (2014). Development and evaluation of the effectiveness of computer-assisted physics instruction. International Education Studies, 7(13), 14-22. doi: https://doi.org/10.5539/ies.v7n13p14

Sattriawan, A., Sutiarso, S., \& Rosidin, U. (2020). Pengembangan media pembelajaran interaktif terintegrasi soft skills dalam meningkatkan kemampuan pemecahan masalah. Jurnal Cendekia: Jurnal Pendidikan Matematika, 04(02), 950-963. doi: https://doi.org/10.31004/cendekia.v4i2.314 [Indonesian]

Septyanti, E., Kurniaman, O., \& Charlina. (2020). Development of interactive media based on adobe flash in listening learning for university student. International Journal of Scientific and Technology Research, 9(1), 74-77. Retrieved from: https://www.ijstr.org/paperreferences.php?ref=IJSTR-1219-26227

Siregar, A. C., Adisaputera, A., \& Yus, A. (2020). The development of interactive media assisted by macromedia flash to improve the ability of understanding the fiction story information in elementary school students. Budapest International Research and Critics in Linguistics and Education (BirLE) Journal, 3(2), 1200-1208. doi: https://doi.org/10.33258/birle.v3i2.1053

Sugiono. (2018). Metode Penelitian Pendidikan. Bandung: Afabeta. [Indonesian]

Susilana, R., \& Riyana, C. (2009). Media Pembelajaran. Bandung: CV Wacana Prima. [Indonesian]

Yanto, D. T. P. (2019). Praktikalitas media pembelajaran interaktif pada proses pembelajaran rangkaian listrik. INVOTEK: Jurnal Inovasi Vokasional Dan Teknologi, 19(1), 75-82. doi: https://doi.org/10.24036/invotek.v19i1.409 [Indonesian] 